\title{
DEMANDE D'ARTICLES
}

La Revue canadienne du vieillissement fera paraître un numéro spécial pour le Vol. 6, No. 2. La publication est prévue pour Mai, 1987

LA GERONTOLOGIE ET LE BIEN-ETRE SOCIAL

Les intéresses sont priès de soumettre leurs articles concernant

LA POLITIQUE DE VIEILLESSE LES SERVICES SOCIAUX
LES DROITS DE L'HOMME ET LES CONDITIONS DEOTONLOGIQUES
LA GERONTOLOGIE ET LA POLITIQUE SOCIALE

Les articles en demande sont ceux qui traitent du bien-être social et la pension de vieillesse, la retraite, les differences régionales, le logement, les modes de distribution des services sociaux, la gériatrie, les conditions familiales, le développement communautaire, les groupes minoritaires, la gérontologie sur le plan international et les procédés pour le développement de la politique de vieillesse.

La CJA/RCV fera la critique de tous les documents soumis.

La date limite pour l'inclusion dans ce numéro est le 31 Decembre, 1986.

Prière d'addresser toute correspondence ou demande de renseignements a:

Lilian Wells

Rédactrice, Bien-Etre Social

Faculté des Services Sociaux

Université de Toronto

246 Bloor Ouest

Toronto, Ontario M5S 1 A1 Canada

\section{REQUEST FOR PAPERS}

The Canadian Journal on Aging/La Revue canadienne du vieillissement plans a special issue for Volume 6, no. 2, scheduled for publication in May, 1987.

\section{GERONTOLOGICAL TRENDS AND ISSUES IN SOCIAL WELFARE}

Authors are invited to submit papers on

POLICY SOCIAL SERVICES
HUMAN RIGHTS AND ETHICAL ISSUES
RELATED ASPECTS OF AGING AND POLICY

Papers are sought which address social welfare issues in relation to pension policy, retirement, regional disparity, housing, patterns of service delivery, long-term care, family policies, community development, multicultural issues, vulnerable groups, international comparisons, and the policy formation process.

All submissions will proceed through CJA/RCV Review Process

Deadline for inclusion in this issue: 31 December, 1986.

Further information: Write:

Lilian Wells

Social Welfare Editor

Faculty of Social Work

University of Toronto

246 Bloor Street West

Toronto, Ontario M5S 1A1 Canada 


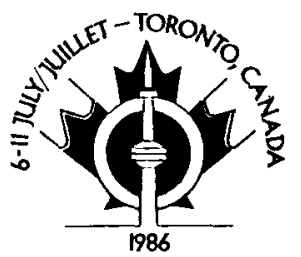

$6^{\text {DINITERAATIONAL }}$ CONGRESS OF IMMUNOLOGY

G" CONGRÉS INTERNATIONAL D'JMMUNOLOGIE
The 6th International Congress of Immunology will take place in Toronto between 6-11 July 1986 and will have the following themes:

1. Developmental Biology of the Immune System

2. Structure and Function of Recognition Structures

3. Regulation of the Immune Response

4. Oncogenesis \& Tumor Immunity

5. Response of the Host to the Environment

6. Host-Graft Relationship

Among the Workshops there will be three of particular interest to Gerontologists:

1. Immunopathology of Aging, chaired by Dr. G. Doria and Dr. R.L. Walford

2. Differentiation and regulatory cell interactions in aging, chaired by Dr. B. Cinader and Dr. M.M.B. Kay

3. Nutrition and Immunity, chaired by Dr. R.K. Chandra and Dr. D.N. McMurray

To obtain Congress literature and registration forms, please contact Mr. Ken Charbonneau, Executive Secretary, 6th International Congress of Immunology, National Research Council of Canada, Ottawa, Ontario K1A 0R6 (Tel: (613) 933-9009).

\section{An International Symposium \\ Nutritional Regulation of Immunity and Infection \\ Toronto, Canada \\ July 3-5, 1986 \\ Organized by the International Nutritional Immunology Group \\ in association with the 6th International Congress of Immunology}

\section{SCIENTIFIC PROGRAM}

Plenary Lectures $\bullet$ Invited Scientific Presentations $\bullet$ Posters

\section{MAIN TOPICS}

Epidemiology

Immune responses in nutritional deficiencies:

Protein-calorie malnutrition, vitamin and trace element deficits

Impact of individual nutrients on immunity

Obesity and immunocompetence

Nutrition, immunity and cancer

Nutrition and infection in surgical and burn patients

Nutrition, immunity and illness in the elderly

Nutrition and autoimmune disorders

Please Note: Space is available for only 150 participants. To ensure participation, early pre-registration is advisable. 


\section{The Riverdale Hospital G E R I A T R I CIA N}

The Riverdale Hospital-a 784 bed Long Term Care and Rehabilitation facility-is currently seeking to add a Geriatrician to the consulting medical staff.

Our hospital is located in downtown Toronto and is presently planning the redevelopment of the facility to create a regional geriatric centre.

The successful candidate will be dedicated to caring for the elderly in order to provide a continuum of care in this commmunity. Please forward your resume to:

The Executive Director The Riverdale Hospital 14 St. Matthews Road

Toronto, Ontario M4M 2B5 


\section{LATER LIFE}

\section{The Social Psychology of Aging edited by VICTOR $W$. MARSHALL}

Later Life is a cohesive study of today's foremost issues in the social psychology of aging. This absorting collection, written by prominent social psychologists in the field of aging. presents varying levels of theorization, both daring and innovative. Based largely on symbolic interactionism and phenomenology, this book examines the basic elements of an interpretive perspective on studies in aging and later life, and critiques prevailing atheoretical and structural-functional approaches in social gerontology. The text concurrently recognizes that aging individuals are embedded in social structural contexts that have their own historical and social imperatives and dynamics.

CONTENTS: 1. Dominant and Emerging Paradigms in the Social Psychology of Aging V.W. MARSHALL, 2. The sibjective Construction of Self and Socien C.I. RYFF / 3. Socialization in OId Age X. CHAPPELL \& H. L. ORBACH 4. Some Contributions of Symbolic Interaction to the Study of Growing Old D.L. SPENCE / 5. A Sociological Perspective on Aging and IVing IW MARSHALL / 6. The Old Person as Stranger J.j. DOW1) , 7. Social Networks and Social Support B. WELLMAN \& A MALL. 8. Friendships in Old Age S H. MATTHEWS / 9. The World We Forgot M. KOHU ; 10. Comparative Perspectives on the Microsociology of Aging V.L. BENGTYON

1986 (Jan.) / 352 pages / \$29.00 (c) (25476) / \$14.95 (p) (25484)

SAGE PUBLICATIONS, Inc.

275 South Beverly Drive, Beverly Hills, CA 90212 


\section{CANADIAN JOURNAL ON AGING}

Instructions to Authors

1. Manuscripts should be sent to:

Dr. Victor W. Marshall

Editor-in Chief,

Canadian Journal on Aging

McMurrich Building

University of Toronto

TORONTO, Ontario M5S 1 A8

2. Articles should by typed double-spaced (including references). Five (5) copies must be submitted.

3. A title page must be included containing name of the author, highest academic degree awarded, name and address of institutional affiliation. A condensed title for a running-page headline, not to exceed $\mathbf{4 0}$ letters and spaces should be supplied, along with up to six (6) key words for abstracting purposes.

4. Abstract. Each author is required to furnish, on a separate sheet, an abstract of not more than 100-150 words. A French translation of the abstract is necessary. The author may provide this or accept the expense of the translation of the abstract.

5. Style of Referencing. The articles submitted should be written in either the American Psychological Association (1984) style or the Vancouver style of referencing. More information regarding this may be obtained by writing to the editorial office.

6. Tables. Tables should be typed on separate sheets.

7. Figures. Figures should be submitted in a form ready for publication. The cost of reproduction of complex figures will be borne by the author. Some photographic reproductions may also result in additional costs to the author.

8. Authors' alterations of the page proofs in excess of $10 \%$ of the cost of the composition will be charged to the author.

9. Submission of a paper to the CJA implies that it has not been published, nor is it under consideration by another journal; and if accepted by the $C J A$ is not to be published elsewhere (except as conference proceedings) without permission.

10. Authors should avoid using sexist language in their manuscripts. For further classification, please refer to the APA guidelines.

Lack of adherence to the instructions may delay consideration of publication.
REVUE CANADIENNE DU VIEILLISSEMENT

\section{Protocole de presentation}

1. Les manuscrits doivent ètre adressés à : Monsieur Victor W. Marshall, Director

Revue canadienne du vieillissement

Pavillon McMurrich

Université de Toronto

TORONTO, Ontario M5S 1A8

2. Les manuscrits (y compris les références bibliographiques) doivent être dactylographiés à double interligne et soumis en cinq (5) exemplaires.

3. Les manuscrits doivent être accompagnés d'une page de titre et comporter les mentions suivantes : nom de l'auteur, dernier diplôme obtenu, nom et adresse de l'employeur, le titre de l'article condensé en vue de figurer dans l'en-tête et ne dépassant pas $\mathbf{4 0}$ caractères tous espaces compris, six (6) mots clés ou moins susceptibles de servir de descripteurs au résumé analytique.

4. Résumé. Les auteurs dont priés de foumir, sur une feuille séparée, un résumé ne dépassant pas 100 à 150 mots. Celui doit être accompagné de sa traduction anglais, à défaut de quoi les frais de traduction sont au compte de l'auteur.

5. Références. La présentation des rèfèrences doit être conforme au protocole de l'American Psychological Association (1984) ou au protocole de Vancouver. Pour obtenir de plus amples renseignements sur ce point s'adresser au Bureau de la revue.

6. Tableaux. Les tableaux doivent figurer sur des feuilles séparées.

7. Schémas et diagrammes. Les illustrations doivent être prètes à reproduire. Les frais occasionnés par la reproduction des illustrations compliquées sont au compte des auteurs. La reproduction des photographies, le cas échéant, peut également entrainer des frais supplèmentaires.

8. Les corrections d'auteur excédant $10 \%$ du coût de la composition sont aux frais des auteurs.

9. La soumission d'un manuscrit à la revue implique que le manuscrit est inédit et n'a pas été proposé à une autre revue. Aucun manuscrit accepté par la $R C V$ ne peut être reproduit sans autorisation (exception faite des comptes rendus et procès verbaux).

10. Les auteurs éviteront d'employer des tournures sexistes. Se reporter aux directives de l'APA.

Si les instructions données ne sont pas suivis, la publication des articles sera retardé. 


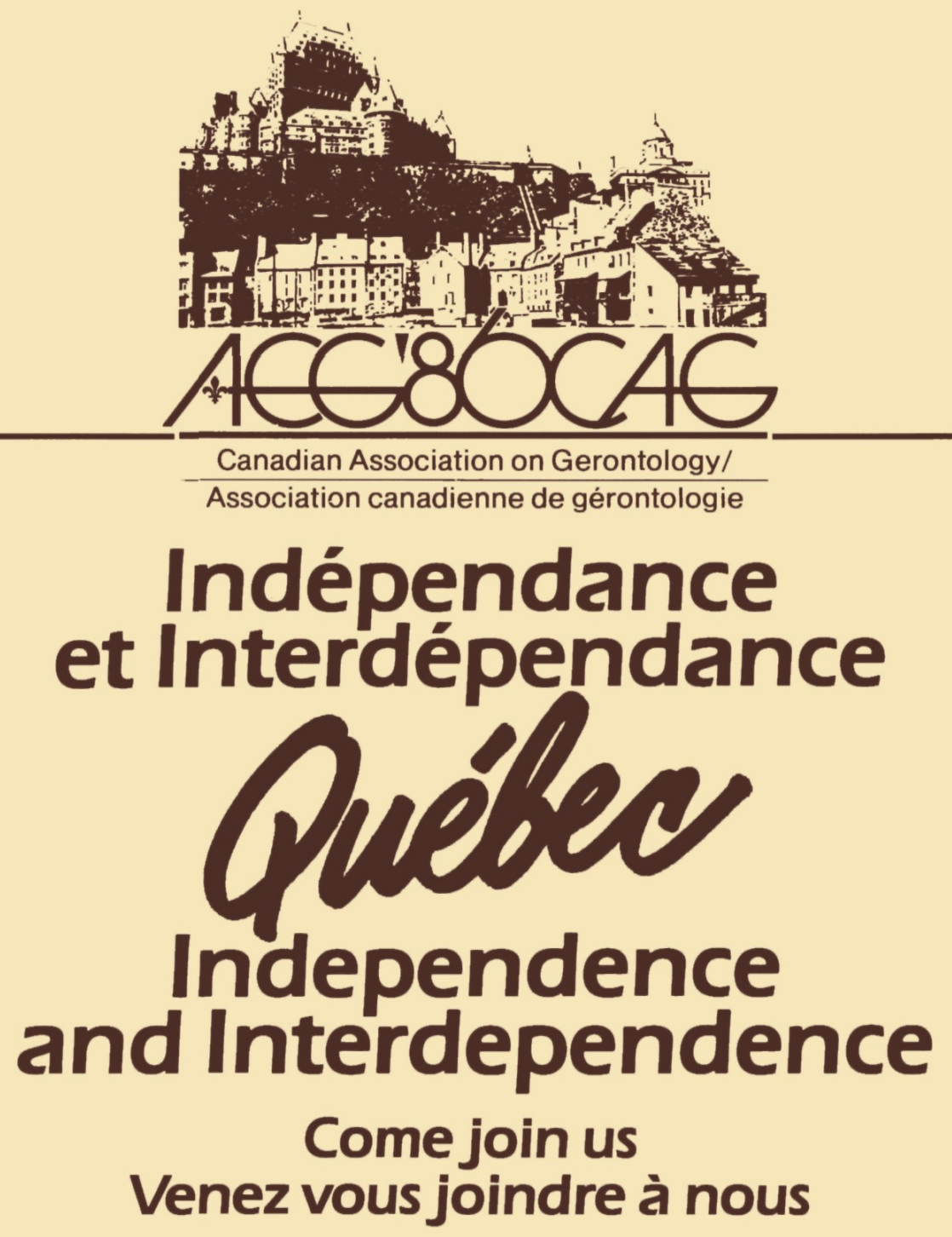

for the/pour la

15th Annual Scientific and Educational Meeting

$15^{\mathrm{E}}$ Réunion scientifique et éducative annuelle of the/de I'

Canadian Association on Gerontology/

Association canadienne de gérontologie

November 2-6 Novembre 1986

Hilton Hotel, Quebec/ Hôtel Hilton, Québec

Quebec

Old France at your door

Québec

Registration materials will be available in August.

For information contact Gilles Barbeau at (418) 656-3211

or Mary Lynn Moffat at (204) 944-9158. 